Note

\section{A Possible Biosynthetic Precursor of 3-Hydroxypicolinic Acid in Etamycin}

\section{Nobuo Nagato, Yasushi OKumura, * Rokuro OKAMOTO and Tomoyuki IsHIKURA}

\author{
Central Research Laboratories, \\ Sanraku-Ocean Co., Ltd., \\ 9-1 Johnan 4-chome, \\ Fujisawa 251, Japan
}

Received April 11, 1984

3-Hydroxypicolinic acid (3-HPA) is found in the virginiamycin B group ${ }^{1)}$ and in pyridomycin. ${ }^{2)}$ For biosynthetic precursors of the 3-HPA moiety in both antibiotics, two precursors have been proposed. Ogawara $e t$ al. reported that ${ }^{14} \mathrm{C}$-labeled L-aspartic acid and glycerol were incorporated into the 3-HPA moiety in pyridomycin, ${ }^{3)}$ while Hook and Vining reported that ${ }^{14} \mathrm{C}$-labeled L-lysine but not L-aspartic acid was incorporated into the 3-HPA moiety in etamycin, one of the virginiamycin B group. ${ }^{4)}$ In the case of etamycin, as the incorporation of ${ }^{14} \mathrm{C}$-labeled L-lysine was extremely low (approx. 0.15\%) and the incorporation time was very long (approx. $72 \mathrm{hr}$ ), it has not been confirmed that Llysine is the precursor of the 3-HPA moiety in etamycin. As a consequence, we have attempted to determine the biosynthetic origin of 3-HPA in etamycin in a short term of incubation.

Streptomyces griseoviridus P8648, one of etamycinproducing micro-organisms, was employed in this study. Cultivation was carried out as described previously. ${ }^{5)} \mathrm{L}$ $\left[{ }^{14} \mathrm{C}-(\mathrm{U})\right] \mathrm{lysine}(300 \mathrm{mCi} / \mathrm{mmol})$ and $\mathrm{L}-\left[{ }^{14} \mathrm{C}-(\mathrm{U})\right]$-aspartic acid $(200 \mathrm{mCi} / \mathrm{mmol})$ were added to the culture at $72 \mathrm{hr}$ after inoculation at the concentration of $0.04 \mu \mathrm{Ci} / \mathrm{ml}$ each. At an appropriate time, $2 \mathrm{ml}$ of the broth was sampled and subjected to analyses of the antibiotic production, incorporation of the labeled amino acids, and distribution of the radioactivities by the methods described previously. ${ }^{5}$ For determination of the biosynthetic pathway of 3-HPA from L-lysine, various compounds listed in Table II were added to the culture at $1 \mathrm{hr}$ before the addition of the labeled L-lysine, and their effects on etamycin production and the incorporation of labeled L-lysine into the antibiotic were determined at $24 \mathrm{hr}$ after the addition of the labeled L-lysine.

The incorporation of ${ }^{14} \mathrm{C}$-labeled $\mathrm{L}$-lysine into the antibiotic was compared with that of ${ }^{14} \mathrm{C}$-labeled L-aspartic acid (Table I). Time course of the incorporation of the labeled L-lysine is shown in Fig. 1. In addition, there was no radioactive residue except 3-HPA detected in etamycin (data not shown). These results sustain the idea that Llysine but not $\mathrm{L}$-aspartic acid is one of the precursors of 3HPA in etamycin.

We have tried to elucidate the biosynthetic pathway of 3-HPA in etamycin from L-lysine. The results are shown in Table II. S-2-Amino-ethyl-L-cysteine, one of the L-lysine analogs, caused a great reduction of not only antibiotic

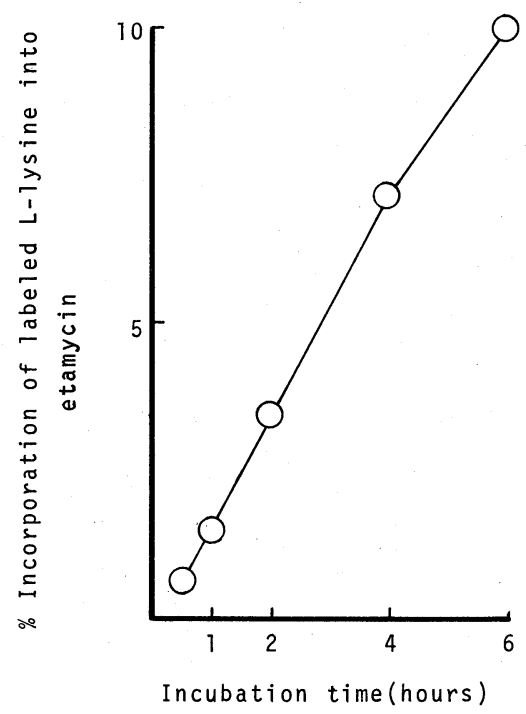

Fig. 1. Time Course of $\mathrm{L}-\left[{ }^{14} \mathrm{C}-(\mathrm{U})\right]$ Lysine Incorporation into Etamycin.

S. griseoviridus P8648 was cultivated in a $250-\mathrm{ml}$ Erlenmeyer flask containing $25 \mathrm{ml}$ of the medium described previously. ${ }^{5}$

\section{TABle I. Comparison of the Incorporation Ratio and ETamyCin Production with $\mathrm{L}-\left[{ }^{14} \mathrm{C}-(\mathrm{U})\right]$ LYSINE AND WITH $\mathrm{L}\left[{ }^{14} \mathrm{C}\right.$-(U)]Aspartic ACID}

$S$. griseoviridus P8648 was cultured in a $250-\mathrm{ml}$ Erlenmeyer flask containing $25 \mathrm{ml}$ of the medium described previously. ${ }^{5)}$ With labeled L-aspartic acid, Lglutamine was used as a nitrogen source instead of $L$ asparagine.

\begin{tabular}{ccc}
\hline Labeled compound & $\begin{array}{c}\text { Antibiotic } \\
\text { production } \\
(\mu \mathrm{g} / \mathrm{ml})\end{array}$ & $\%$ incorporation \\
\hline L- $\left[{ }^{14} \mathrm{C}-(\mathrm{U})\right] \mathrm{Lys}$ & 62 & 18.0 \\
$\mathrm{~L}-\left[{ }^{14} \mathrm{C}-(\mathrm{U})\right] \mathrm{Asp}$ & 60 & 0.1 \\
\hline
\end{tabular}

* To whom all correspondence should be addressed. 
TABLE II. INFLUENCES OF VARIOUS COMPOUNDS UPON THE INCORPORATION OF LABELED L-LYSINE INTO ETAMYCIN AND THE ANTIBIOTIC Production

\begin{tabular}{lccc}
\hline Compound & $\begin{array}{c}\text { Concn. } \\
(\mathrm{mM})\end{array}$ & $\begin{array}{c}\text { Etamycin } \\
\text { production } \\
(\% \text { control })\end{array}$ & $\begin{array}{c}\text { Labeled } \\
\text { L-lysine } \\
\text { incorporation } \\
(\% \text { control })\end{array}$ \\
\hline Control & - & 100 & 100 \\
S-2-AEC & 1 & 15 & 18 \\
DL-DAP & 2 & 100 & 100 \\
DL-AAA & 2 & 100 & 95 \\
L-Pip & 1 & 100 & 90 \\
L-Saccharopine & 1 & 95 & 90 \\
DL-Hylys & 2 & 100 & 53 \\
L-Hypip & 1 & 105 & 24 \\
3-HPA & 1 & 120 & 10 \\
PA & 1 & 100 & 100 \\
2,3-PDA & 1 & 100 & 100 \\
L-Try & 1 & 95 & 100 \\
\hline
\end{tabular}

Abbreviations: $S$-2-AEC, $S$-2-aminoethyl-L-cysteine; DL-DAP, DL-diaminopimelic acid; DL-AAA, DL-2aminoadipic acid; L-Pip, L-pipecolic acid; DL-Hylys, 5hydoxyl-DL-lysine; L-Hypip, 5-hydroxy-L-pipecolic acid; 3HPA, 3-hydroxypicolinic acid; PA, picolinic acid; 2,3PDA, 2,3-pyridine dicarboxylic acid. production but also lysine incorporation. The other compounds except 3-HPA scarcely affected the antibiotic production. 3-HPA slightly enhanced the antibiotic production. On the other hand, 3-HPA, 5-hydroxy-Lpipecolic acid, and 5-hydroxy-DL-lysine significantly reduced the incorporation of labeled L-lysine into the antibiotic. This suggests that a free form of 3-HPA derived from L-lysine is a direct precursor of the 3-HPA moiety in etamycin, and that 5-hydroxy-L-pipecolic acid and 5hydroxy-DL-lysine may also be precursors of 3-HPA in etamycin. Furthermore, since picolinic acid is not a precursor of 3-HPA in etamycin, the hydroxy group at the C3 position of 3-HPA may be introduced into the pyridine ring of picolinic acid before the pyridine ring formation.

\section{REFERENCES}

1) Y. Okumura, "Biochemistry and Genetic Regulation of Commercially Important Antibiotics," ed. by L. C. Vining, Addison-Wesley Publishing Co., Massachusetts, 1983, pp. 147 178.

2) K. Maeda, H. Kosada, Y. Okami and H. Umezawa, J. Antibiot., 6A, 140 (1953).

3) H. Ogawara, K. Maeda and H. Umezawa, Biochemistry, 7, 3296 (1968).

4) D. J. Hook and L. C. Vining, Can. J. Biochem., 51, 1630 (1973).

5) Y. Okumura, M. Onishi, R. Okamoto and T. Ishikura, Agric. Biol. Chem., 46, 3063 (1982). 